\title{
RECYCLING PRACTICES AND PERCEPTIONS AMONG RURAL PRIMARY SCHOOL CHILDREN IN SJK CHUNG HUA ASAJAYA, SAMARAHAN, SARAWAK
}

\author{
Parveen Kaur \\ Universiti Malaysia Sarawak \\ sspkaur@unimas.my \\ Chai Nyet Foong \\ Wawasan Open University \\ Arif Jawaid \\ Linton University College
}

*Corresponding author sspkaur@unimas.my 


\title{
of Borneo Kalimantan JBK Volume 3 Issue 2 (DECEMBER 2017) Special Issue \\ Institute of Borneo Studies \\ Universiti Malaysia Sarawak \\ RECYCLING PRACTICES AND PERCEPTIONS AMONG RURAL PRIMARY SCHOOL CHILDREN IN SJK CHUNG HUA ASAJAYA, SAMARAHAN, SARAWAK
}

\begin{abstract}
Recycling is one of the best ways to have a positive impact on the world in which we live in. In this modern hectic world of ours, people are indulging in activities which harm the environment. It is vital to educate our future generation in the preservation of our pleasant environment by not only polluting but also spreading crucial diseases. The purpose of this research is to understand the recycling practices and perceptions among rural primary school children. The sample for this study included Primary Three to Primary Six (N=16, M=11.31 years) school children with different ages and ethnic groups. The research was carried out in SJK Chung Hua Asajaya, Samarahan, Sarawak. This study used both qualitative and quantitative methods to collect the data. Face-to-face interviews guided by questionnaires as a tool determine the habits and practices on recycling activity. Findings of this study indicated that majority of the school children have good habits of recycling in both school and at home. Their perceptions indicated that they were aware on the importance of recycling in preserving the environment. This study would benefit the people in rural areas to be aware on the importance of recycling and how they can practice and improve their habits in recycling. School plays an important role in cultivating this practice. Recycling will help the town council and related institutions to give individuals a better quality of living.
\end{abstract}

Keywords: recycle, practices, perception, children, rural, Sarawak. 